\title{
Community Based, Resources Dependent Livelihood: A Case Study at Kodikulam Village, Madurai East, Tamilnadu
}

\author{
V. Padmavathy ${ }^{1}$, D. Winfred Thomas ${ }^{2}$, K. Chandramohan ${ }^{3}$ \\ ${ }^{1}$ Department of Botany, The American College, Madurai, Tamil Nadu \\ ${ }^{2}$ Head (Undergraduate), Department of Botany, The American College, Madurai, Tamil Nadu \\ ${ }^{3}$ UCG-Academic Staff College, Madurai Kamraj University, Madurai, Tamil Nadu
}

\begin{abstract}
While the new global environmental governance status is transforming and the world leaders are trying to rank polluters and disowning their responsibilities of global level cleaning operations, our study revealed that grassroots level communitieswithout any influence from the above, continue their efforts that mitigate local climate changes that affect their daily life. Global governance hasno significant impact on their livelihood strategies and struggles for acquiring their daily bread.
\end{abstract}

Keywords: Global Environmental Governance, Polluters, Grass Root Level, Communities,

\section{Introduction}

This work conducted at Kodikulam for two years with 700 people in the village presents the results as elements for universal narratives .As discussed by Annika et.al (2017)it is explored that what future changes the Kodikulam region economically, environmentally and socially within one to two generations, and perspectives of local and regional actors to bring chronicles about global change.

Natural resources management is a vital part of the Indian society. Such managerial practices has evolved from communities that are closely associated with environment, giving rise to recurring practices for the better utilization and conservation of the bioresources. This field based study conducted at Kodikulam village, Madurai, Tamilnadu (2014-
2016) highlights the importance of traditional knowledge in self-organization of resources ownership, maintenance, management and protection. Even in limited land availability Kodikulam village is self-sufficient in food production, by its higher level productivity and other supplementary activities. The people of Kodikulam are rich in indigenous knowledge and are capable of obtaining all necessary requirements from available resources is explained in the table 1 and typical landscape utilization is illustrated in figure 1. Similar to the work of Padmavathy et al (2017), the present study focuses on a community that is able to contribute significantly to natural landscapes, with sustainable development that enhances the livelihood security and ensures the quality of life.

Table 1: Indicating landscapes and best possible utilization out of it

\begin{tabular}{|c|c|c|c|c|c|c|}
\hline \multicolumn{2}{|c|}{ Landscape } & Names of the User groups involved & $\begin{array}{c}\text { Area } \\
\text { (in } \\
\text { hectares) }\end{array}$ & $\begin{array}{l}\text { Percentage } \\
\text { of people } \\
\text { involved }\end{array}$ & Resources available & $\begin{array}{l}\text { Average } \\
\text { distance } \\
\text { travelled for } \\
\text { the landscape }\end{array}$ \\
\hline $\begin{array}{l}\text { Level 1 } \\
\text { Build up land } \\
\text { (settlement } \\
\text { area) }\end{array}$ & $\begin{array}{c}\text { Level } 2 \\
\text { Residential area } \\
\text { Commercial and } \\
\text { services } \\
\text { Other build up land } \\
\text { roads }\end{array}$ & $\begin{array}{l}\text { - Cockfight Promoters(Local Breed) } \\
\text { - Non Wood Product Contractors } \\
\text { - Compost and Manure Producers } \\
\text { - Small scale gardeners } \\
\text { - Medicinal Plant Traders }\end{array}$ & & $\begin{array}{l}4 \% \\
26 \% \\
32 \% \\
24 \% \\
14 \%\end{array}$ & $\begin{array}{c}\text { Tamarind trees } \\
\text { Livestock }\end{array}$ & \\
\hline $\begin{array}{l}\text { Agricultural } \\
\text { land }\end{array}$ & $\begin{array}{l}\text { Crop land and } \\
\text { pasture } \\
\text { nurseries }\end{array}$ & $\begin{array}{l}\text { - } \text { Farmers (landlords) } \\
\text { - Agricultural laborers (landless } \\
\text { laborers) } \\
\text { - Mushroom Gathers }\end{array}$ & & $\begin{array}{c}3 \% \\
88 \% \\
9 \%\end{array}$ & $\begin{array}{c}\text { Fodder } \\
\text { Mushrooms }\end{array}$ & \\
\hline Range land & $\begin{array}{l}\text { Herb, shrub and } \\
\text { brush rangeland }\end{array}$ & $\begin{array}{l}\text { - Palm Craftsmen } \\
\text { - Fodder Cultivators } \\
\text { - Fuel Wood gatherers } \\
\text { - Medicinal Plants collectors } \\
\text { - Insect Gathers (Food and Feed) }\end{array}$ & & $\begin{array}{l}23 \% \\
27 \% \\
30 \% \\
15 \% \\
5 \%\end{array}$ & $\begin{array}{l}\text { Palm trees } \\
\text { Fodder } \\
\text { Fuel wood trees } \\
\text { Insects } \\
\text { Medicinal plants }\end{array}$ & \\
\hline Forest land & $\begin{array}{l}\text { Deciduous forest } \\
\text { land }\end{array}$ & $\begin{array}{l}\text { - Fuel Wood gatherers } \\
\text { - Fodder Cultivators } \\
\text { - Carpenters }\end{array}$ & & $\begin{array}{c}30 \% \\
27 \% \\
3 \%\end{array}$ & $\begin{array}{c}\text { Palm trees } \\
\text { Fodder } \\
\text { Fuel wood trees }\end{array}$ & \\
\hline
\end{tabular}




\section{International Journal of Science and Research (IJSR)}

ISSN (Online): 2319-7064

Index Copernicus Value (2015): 78.96 | Impact Factor (2015): 6.391

\begin{tabular}{|c|c|c|c|c|}
\hline & & $\begin{array}{ll}\text { - } & \text { Palm Craftsmen } \\
\text { - Hunters(Game Animals) } \\
\text { - Insect Gathers (Food and Feed) } \\
\text { - Medicinal Plants / Wild fruit } \\
\text { Collectors } \\
\end{array}$ & $\begin{array}{c}23 \% \\
4 \% \\
3 \% \\
10 \%\end{array}$ & \begin{tabular}{|c|} 
Insects \\
Medicinal plants \\
Small birds and animals \\
Wild fruits
\end{tabular} \\
\hline $\begin{array}{l}\text { Out crop(hill } \\
\text { or mountain } \\
\text { region) }\end{array}$ & - & $\begin{array}{l}\text { - Honey Gathers } \\
\text { - Hunters } \\
\text { - (Game Animals) } \\
\end{array}$ & $\begin{array}{l}56 \% \\
44 \%\end{array}$ & \begin{tabular}{|c|} 
Honey combs \\
Small birds and animals \\
\end{tabular} \\
\hline Fallow land & - & $\begin{array}{l}\text { - Fodder Cultivators } \\
\text { - Fuel Wood gatherers } \\
\text { - Medicinal Plants collectors } \\
\text { - Insect Gathers (Food and Feed) }\end{array}$ & $\begin{array}{c}27 \% \\
0 \% \\
15 \% \\
5 \%\end{array}$ & \begin{tabular}{|c|} 
Fodder \\
Fuel wood trees \\
Insects \\
Medicinal plants \\
\end{tabular} \\
\hline Water & $\begin{array}{l}\text { Streams } \\
\text { Canals } \\
\text { tanks }\end{array}$ & $\begin{array}{l}\text { - Fishing community } \\
\text { - Mushroom Gathers } \\
\text { - Insect Gathers (Food and Feed) }\end{array}$ & & $\begin{array}{c}\text { Fishes } \\
\text { Mushrooms } \\
\text { Insects } \\
\end{array}$ \\
\hline
\end{tabular}

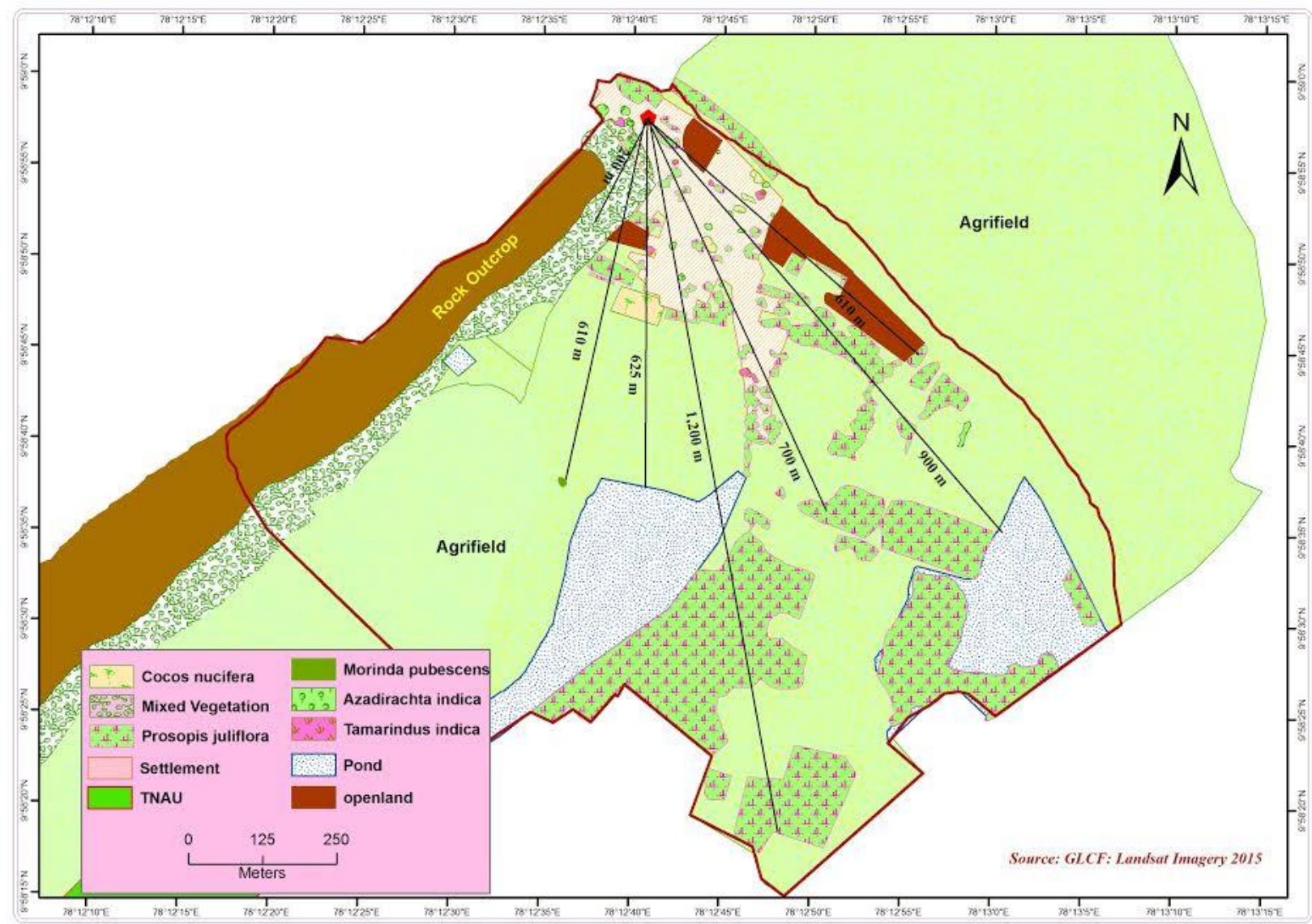

Figure 1: Depicting the landscape mapping of Kodikulam site

Government proposes many offers for rural based living people. But as far as their expenditures are concerned their dependency on resources are high than the other deals of the government (for instance, one $\mathrm{kg}$ of LPG (Rs.450) is equivalent to 7 Kilograms of fuel wood (free)). Similar study conducted by Udmale (2014) in Maharashtra state recommended the government to give special attention to local people's perception while designing and formulating policies for increasing community resilience towards the future varying climatic events. Over generations the local community of Kodikulam had developed locally adapted, location specific traditional and indigenous practices that paves way for self-administration, community livelihood, food security and conservation of natural resources.

Using low technology and with limited landscape, strategies and coping mechanism using alternate occupations,
Kodikulam stands as an example of great significance for economic stability, ecological resiliency, managerial skills even in extreme weather and climatic conditions. Ostrom (1996) defines the theory of co-production mentioning that there is no remark of village governance or local governance, which is the only governance that has an impact directly on the lives of most people. Hence establishing local level research and effective employment of traditional knowledge would act as a basement for self-reliant development that would enhance the national food security in the face of climatic variability.

\section{References}

[1] Annika E. Nilssona ,, Ingrid Bay-Larsen, Henrik Carlsen, Bob van Oort, MaikenBjørkan, KirstiJylhä, Elena Klyuchnikova, Vladimir Masloboev, Lize-Marié van der

\section{Volume 6 Issue 7, July 2017}




\section{International Journal of Science and Research (IJSR) \\ ISSN (Online): 2319-7064}

Index Copernicus Value (2015): 78.96 | Impact Factor (2015): 6.391

Watt Towards extended shared socioeconomic pathways: A combinedparticipatory bottom-up and top-down methodology with results from theBarents region Global Environmental Change 452017 124-132

[2] Ostrom.E.(1996).Crossing the great divide. Coproduction, synergy and development. World development, 24(6),1073-1087

[3] Padmavathy.V, Winfred Thomas.D, Chandramohan.K 2017 Community led management in conserving biodiversity and managing natural resources using traditional knowledge: a case study on Kodikulam village, Madurai, Tamilnadu International Research Journal of engineering and Technology Vol 3,Issue-1 ISSN:2454-1362

[4] ParmeshwarUdamle, Yutaka Ichikawa, SujataManandhar, Hiroshi Ishidaira, Anthony.S.KiemFarmer's perception of drought impacts, local adaptation and administrative mitigation measures in Maharastra state India International journal of Disaster Risk Reduction 2014 10, 250-269. 